\title{
Enhancing Soil Health and Productivity of Maize - Wheat Cropping System with Balanced Nutrients Application through Target Yield Approach under Different Tillage Practices
}

\author{
K. A. Hiremath*, A. S. Halepyati, B. M. Dodamani, M. A. Bellakki, \\ B. M. Chittapur, P. H. Kuchanur and Ameregouda \\ Department of Agronomy, University of Agricultural Sciences, Raichur - 584104 \\ (Karnataka), India \\ *Corresponding author
}

\section{Keywords}

Tillage, Crop residue, Mulch, Target yield, System productivity

Article Info

Accepted:

08 January 2020

Available Online:

10 February 2020

\section{A B S T R A C T}

A study was carried out during kharif and rabi seasons of 2013-14 and 2014-15 at Agricultural Research Station, Bheemarayanagudi to study about enhancing soil health and productivity of maize - wheat cropping system with balanced nutrients application through target yield approach under different tillage Practices. The results indicated that the growth and yield parameters of maize and wheat at harvest did not influence due to tillage practices. All these yield parameters were relatively higher in zero tillage with mulch@ $5 \mathrm{t} \mathrm{ha}^{-1}$ when compared to conventional tillage. Grain and stover yield of maize did not differ significantly due to different tillage management practices. But, zero tillage with mulch @ $5 \mathrm{t} \mathrm{ha}^{-1}$ produced relatively higher yield $\left(65.9 \mathrm{q} \mathrm{ha}^{-1}\right)$ than the zero tillage $\left(64.3 \mathrm{q} \mathrm{ha}^{-1}\right)$ followed by conventional tillage $\left(55.8 \mathrm{q} \mathrm{ha}^{-1}\right)$. The higher organic carbon and soil microflora at different stages were noticed with zero tillage with mulch@ $5 \mathrm{t} \mathrm{ha}^{-1}$. The higher available NPK and their uptake by maize crop were also recorded in zero tillage with mulch @ $5 \mathrm{t} \mathrm{ha}^{-1}$ followed by zero tillage compared to conventional tillage and zero tillage. The lower available NPK and their uptake by maize crop were recorded in conventional tillage and RDF. Further, due to nutrient management practices, the yield parameters of maize differed significantly. Target yield of $10 \mathrm{t} \mathrm{ha}^{-1}$ exhibited significantly higher growth and yield attributes at harvest when compared to other treatments except targeted yield of $8 \mathrm{t} \mathrm{ha}^{-1}$ and $150 \%$ RDF. The lowest values of these attributes were recorded in farmer's practice of nutrient management followed by RDF. The grain yield and stover yield ( $69.9 \mathrm{q} \mathrm{ha}^{-1}$ and $89.5 \mathrm{q} \mathrm{ha}^{-1}$, respectively) of maize was significantly higher with targeted yield of $10 \mathrm{tha}^{-1}$ followed by targeted yield of $8 \mathrm{tha}^{-1}$ and $150 \% \mathrm{RDF}$. The lowest grain and stover yield (53.6 q ha ${ }^{-1}$ and $74.3 \mathrm{q} \mathrm{ha}^{-1}$, respectively) was recorded in farmers practice followed by RDF. Significantly higher soil microflora, available NPK and their uptake by the maize crop was noticed in target yield of $10 \mathrm{t} \mathrm{ha}^{-1}$ followed by targeted yield of $8 \mathrm{t} \mathrm{ha}^{-1}$ and $150 \% \mathrm{RDF}$ as compared to other treatments. The lowest soil microflora, available NPK and their uptake by the maize was recorded in farmers practice followed by RDF. Non significant differences for grain and stover yield of maize was recorded due to interaction of tillage and nutrient management practices. Similar trend was also followed due to interaction of tillage and nutrient management practices for succeeding wheat. The yield and yield parameters of wheat did not differ due to tillage practices and target yield approaches followed for maize. Maize equivalent yield of wheat and system productivity were followed same trend as that of maize yield. Among different tillage practices, zero tillage (Rs. 78,181 ha ${ }^{-1}$ and 2.19) and zero tillage with mulch @ $5 \mathrm{t}$ $\mathrm{ha}^{-1}$ (Rs. 80,272 $\mathrm{ha}^{-1}$ and 2.18) were recorded maximum net returns and higher BC ratio respectively. Similarly among different nutrient management practices, the target yield of $10 \mathrm{tha}^{-1}$ (Rs. 85,105 and 2.18) followed by targeted yield of $8 \mathrm{t} \mathrm{ha}^{-1}$ (Rs. 80,565 and 2.17) were recorded maximum net returns and higher $\mathrm{BC}$ ratio respectively as compare to other treatments. 


\section{Introduction}

In Karnataka, upper krishna and tunga bhadra projects are being the largest irrigation projects. Rice - Rice is the predominant cropping system being adopted by the farmers' long back in this command area. At present, the system being practiced is creating lot of problems with respect to sustainability in crop production and lands are increasingly becoming unproductive. Of the several options available, adoption of alternate novel crop rotation appears to be promising. Maize has become an alternate crop to be integrated in rice-rice system replacing one rice crop especially during winter or replacing rice rice by alternate and profitable system involving maize - wheat sequence. Though, there are some indications of stagnation or even decline in the productivity of this cropping system due to decreased soil organic matter, over exploitation of nutrients reserve, loss of nutrients and non availability of cost effective fertilizer. Further, the application of inorganic fertilizers even in balanced form may not sustain soil fertility and productivity under continuous cropping. Zero tillage with crop residues management is capable of increasing the soil health and quality by improving soil properties, minimizing soil erosion, soil water evaporation and conserving soil moisture which has been well documented. Hence, reduced tillage practices have been widely used in the last decade as an attractive alternative over conventional tillage practice because of their potential to reduce production or operating costs and benefit for the environment and can save considerable time with seed bed preparation compared with conventional tillage practices. As tillage is mainly confined to surface layers, it increases microbial biomass (Alvear et al., 2005). The zero tillage with direct seeding in presence of residues is capable of building organic matter and soil microbial biomass (bacteria, actinomycetes and fungi). Further it is known to change in pore size distribution as a consequence of reduced tillage (Mann et al., 2008). Incorporation of crop residues is essential for sustaining soil productivity through replenishing soil organic matter which is a key indicator of soil quality, but it also supplies essential nutrients upon mineralization (N, P and $\mathrm{S}$ ) and improves soil physical, chemical and biological properties. Crop residue retention increases the populations of actinomycetes, total bacteria and fluorescent Pseudomonas under both zero and conventional tillage (Govaerts et al., 2008).

Site specific nutrient management (SSNM) is one tool employed to apply nutrients at right rate, right source, right time with right method based on the soil test value for getting higher yields and to save nutrients. Among the several technologies for nutrient management, the site specific nutrient management is seen as one of the main objectives in present scenario of agriculture. It is one of the techniques most relevant to Indian Farming community. Farming has to be treated as another business during these days and we must try to maximize the resource available to us in the most efficient manner possible. Due to the importance of plant nutrition and its influence on crop yield and quality, it is expected that SSNM (Target yield approach) would improve the economic and environmental outcome of crop production. It is an approach for need based feeding of the crops with nutrients (Dhillon et al., 2006). The approach further aims at increasing farmers profit by achieving the goal of maximum crop yields. Further under irrigated condition, there is an opportunity to take two crops in a year following maize-wheat and maize-chickpea cropping systems in order to get efficient utilization of existing available resources. Such kind of cropping system needs full season nutrient requirement through nutrient supply system on sustainable 
manner. There are many options that are available to fulfill the requirement of nutrients regularly in cropping system while keeping the productivity of land sustainable.

Therefore, an investigation was undertaken to study the effect of tillage and nutrient management on soil health and productivity of maize - wheat cropping system under UKP command

\section{Materials and Methods}

The study was conducted during kharif and rabi seasons of 2013-14 and 2014-15 at Agricultural Research Station, Bheemarayanagudi, University of Agricultural Sciences, Raichur, Karnataka. The soil of the experimental site was medium deep black soil with $7.90 \mathrm{pH}$. The soil was low in available nitrogen (207 kg ha $\left.{ }^{-1}\right)$, high in available phosphorus (52.3 kg ha $\mathrm{kg}^{-1}$ ) and high in available potassium (344 $\left.\mathrm{kg} \mathrm{ha}^{-1}\right)$. The organic carbon content of the soil was low $(0.49 \%)$. The Agricultural Research Station represents the UKP command where in rice rice, chilli and cotton are the predominant crops. The rainfall during cropping seasons in the year 2013 - 14 and $2014-15$ received 759 $\mathrm{mm}$ and $646 \mathrm{~mm}$ respectively. The experiment was laid out in split plot design consists of three main plots viz., conventional tillage, zero tillage and zero tillage with mulch@ $5 \mathrm{t} \mathrm{ha}^{-1}$ and six sub plots viz., target yield $\left(6 \mathrm{t} \mathrm{ha}^{-1}\right)$, target yield $\left(8 \mathrm{t} \mathrm{ha}^{-1}\right)$, target yield $\left(10 \mathrm{t} \mathrm{ha}^{-1}\right)$, RDF, $150 \%$ RDF and farmers practice in three replications. The hybrid 900M was used for maize and the variety DWR 198 was used for wheat. The fertilizers were applied as per treatments for maize. For wheat, the fertilizers were applied as per the recommendation. Pre emergent herbicide pendimethalin 30 EC @ $2.5 \mathrm{~kg} \mathrm{ha}^{-1}$ was used to control weeds in initial stage in maize as well as in wheat. Post emergent herbicide 2, 4 - D $80 \% @ 1.25 \mathrm{~kg} \mathrm{ha}^{-1}$ was used for suppressing the weed growth in maize and wheat at 25 DAS. Other agronomic practices were followed commonly in all the treatments as per the recommendations.

\section{Results and Discussion}

\section{Effect of crop residue and tillage management practices on maize}

The data revealed that the grain yield and stover yield of maize did not differ due to different tillage practice. However the numerically higher grain yield (65.9 $\left.\mathrm{q} \mathrm{ha}{ }^{-1}\right)$ and stover yield of maize (88.3 $\left.\mathrm{q} \mathrm{ha}^{-1}\right)$ were noticed with zero tillage with mulch @ $5 \mathrm{t} \mathrm{ha}^{-}$ 1 followed by zero tillage $\left(64.3 \mathrm{q} \mathrm{ha}^{-1}\right.$ and $84.2 \mathrm{q} \mathrm{ha}^{-1}$ respectively). Numerically the lowest grain yield and stover yield were recorded in conventional tillage $\left(55.8 \mathrm{q} \mathrm{ha}^{-1}\right.$ and $76.2 \mathrm{q} \mathrm{ha}^{-1}$ respectively). The higher value of grain yield could be attributed to relatively higher cob length $(14.92 \mathrm{~cm})$, cob girth (12.87 $\mathrm{cm})$, number of grains per cob(426.71), grain weight per plant $(184.91 \mathrm{~g})$ and test weight $(24.58 \mathrm{~g})$. The lowest cob length $(12.71 \mathrm{~cm})$, cob girth $(10.99 \mathrm{~cm})$, grain weight per plant $(169.88 \mathrm{~g})$ and test weight $(22.70 \mathrm{~g})$ were recorded in conventional tillage. These results are in accordance with those obtained by Prashanth and Patil (2013), Singh et al., (2013), Bahar (2013) and Yaseen et al., (2014). The differences in yield parameters due to different tillage practices can be attributed to favourable conditions created by zero tillage or/with mulch for uptake of nutrients. Further this treatment was found to be better in recording higher stover yield and harvest index. The uptake of NPK, organic carbon, available nitrogen and potassium did not differ due to tillage practices. The soil microflora at initial and middle stage was influenced significantly by tillage practices and did not differ at harvest. The higher uptake of NPK, organic carbon, available NPK and improved microbial activity were 
recorded in zero tillage with mulch @ $5 \mathrm{t} \mathrm{ha}^{-1}$ compared to conventional tillage and zero tillage. The lower uptake of NPK, organic carbon, available NPK and microbial activity were recorded in conventional tillage. The increase in the values of these parameters could be due to accumulation of organic matter through zero tillage or zero tillage with mulch. Results are in agreement with findings of Jat et al., (2010) and Prashanth and Patil (2013).

\section{Effect of nutrient management practices (target yield approach) on maize}

In the present study, the effect of nutrient application through targeted yield approach exerted significant influence on the grain yield of maize. The highest grain yield of maize was obtained with target yield of $10 \mathrm{t}$ $\mathrm{ha}^{-1}\left(69.90 \mathrm{q} \mathrm{ha}^{-1}\right)$ followed by target yield of $8 \mathrm{t} \mathrm{ha}^{-1}\left(65.8 \mathrm{q} \mathrm{ha}^{-1}\right)$ and by $150 \%$ RDF (64.0 $\left.\mathrm{q} \mathrm{ha} \mathrm{h}^{-1}\right)$. The significantly lower grain yield was observed in farmers' practice $(53.6 \mathrm{q}$ $\left.\mathrm{ha}^{-1}\right)$ followed by RDF (56.2 q ha $\left.{ }^{-1}\right)$. Significantly higher stover yield was recorded in target yield of $10 \mathrm{t} \mathrm{ha}^{-1}\left(89.5 \mathrm{q} \mathrm{ha}^{-1}\right)$ followed target yield of $8 \mathrm{t} \mathrm{ha}^{-1}\left(86.7 \mathrm{q} \mathrm{ha}^{-1}\right)$ and $150 \% \operatorname{RDF}\left(85.7 \mathrm{q} \mathrm{ha}^{-1}\right)$. The lower stover yield was recorded in farmers' practice (74.3 $\mathrm{qha}^{-1}$ ) followed by RDF (78.3 q ha-1). The increase in grain yield of maize in target yield of $10 \mathrm{t} \mathrm{ha}^{-1}$ and target yield of $8 \mathrm{t} \mathrm{ha}^{-1}$ was 30.41 and 22.76 per cent respectively over farmers' practice and 24.38 and 17.1 per cent respectively over RDF. Higher grain yield of maize could be attributed due to higher cob length, cob girth, number of grains per plant (462.30), grain weight per plant $(188.77 \mathrm{~g})$ and test weight $(25.14 \mathrm{~g})$ due to balanced supply of more nutrients and higher uptake of NPK, organic carbon, available NPK and improved soil microbial activity. Markedly lesser cob length, cob girth, number of grains per plant (313.26), grain weight per plant $(163.80 \mathrm{~g})$ and test weight $(21.76 \mathrm{~g})$ were recorded in farmers' practice followed by RDF. This could be attributed to less quantity of total nutrients supplied under these treatments resulting in the reduction of yield parameters. These results corroborated with the findings of Paramasivan et al., (2012) and Ashok Biradar and Jayadeva (2013). Significantly higher uptake of $\mathrm{N}$ $\left(173.08 \mathrm{~kg} \mathrm{ha}^{-1}\right)$ was noticed with target yield of $10 \mathrm{t} \mathrm{ha}^{-1}$ and it remained at par with targeted yield of $6 \mathrm{tha}^{-1}$, targeted yield of $8 \mathrm{t}$ $\mathrm{ha}^{-1}$ and $150 \%$ RDF. The lowest nitrogen uptake $\left(132.90 \mathrm{~kg} \mathrm{ha}^{-1}\right)$ was observed in farmers' practice and it was inturn found on par with targeted yield of $6 \mathrm{t} \mathrm{ha}^{-1}$ and RDF. The data on phosphorus and potassium uptake followed the same trend as that of nitrogen. Higher nutrient uptake is well reflected in terms of higher grain and stover yields of maize. The results are in conformity with the findings of Shreeharshakumar and Gaddanakeri (2015) and Ramachandrappa et al., (2015).

Soil organic carbon varies significantly among the treatments. It varied from 0.43 to 0.56 per cent in soil after harvest of the crop. Soil is medium in organic carbon content. The organic carbon in soil was increased from 0.50 per cent to 0.56 per cent in target yield from 6 to $10 \mathrm{t} \mathrm{ha}^{-1}$. The organic carbon ranged from 0.43 per cent to 0.51 per cent in other treatments. This clearly indicated that increasing the dose of nutrients could be attributed towards higher organic carbon content. These results are confirmed with the findings of Prashanth and Patil (2013).

The available nitrogen due to target yield approaches followed same trend as that of organic carbon. The data with respect to available phosphorus indicated that significantly higher available phosphorus (55.48 $\mathrm{kg} \mathrm{ha}^{-1}$ ) was recorded with $\mathrm{S}_{3}$ Targeted yield $10 \mathrm{t} \mathrm{ha}^{-1}$ followed by targeted yield of $8 \mathrm{t} \mathrm{ha}^{-1}$ and $150 \%$ RDF. Significantly 
lower available phosphorus (42.64 $\mathrm{kg} \mathrm{ha}^{-1}$ ) was noticed with farmers' practice followed by RDF. Similarly, significantly higher available potassium (360.83 $\left.\mathrm{kg} \mathrm{ha}^{-1}\right)$ was recorded with targeted yield of $10 \mathrm{t} \mathrm{ha}^{-1}$ followed by targeted yield of $8 \mathrm{t} \mathrm{ha}^{-1}$ and $150 \%$ RDF. Significantly the lowest available potassium $\left(277.02 \mathrm{~kg} \mathrm{ha}^{-1}\right)$ was noticed with farmers' practice followed by targeted yield of $6 \mathrm{t} / \mathrm{ha}$ and RDF. The addition of balanced and high dose of NPK fertilizer has increased the available nutrient pool. These results are in confirmity with the findings of Sharma and Jain (2014) and Poonia et al., (2015).

The data pertaining to soil micro flora was affected significantly due to target yield approach treatments at initial and middle stage of crop, but these treatments had no influence at harvest. Similarly, with regard to target yield approach treatments, relatively higher soil micro flora $\left(58.06 \times 10^{6} \mathrm{CFU} \mathrm{g}^{-1}\right.$, and $66.71 \times 10^{6} \mathrm{CFU} \mathrm{g}^{-1}$ at initial and middle respectively) was recorded with target yield approach of $10 \mathrm{t} \mathrm{ha}^{-1}$. There was increase of microbial population at middle stage of crop compared to initial population in all the treatments. The application of nutrients with targeted yield approach increased the organic carbon in soil that in turn leads to higher microbial population.

The lowest soil micro flora $\left(44.13 \times 10^{6} \mathrm{CFU}\right.$ $\mathrm{g}^{-1}$, and $52.66 \times 10^{6} \mathrm{CFU} \mathrm{g}^{-1}$ at initial and middle stage of crop, respectively) was recorded with farmers' practice. This might be due to the lower availability of organic matter and unfavorable condition in the soil which resulted in lesser microbial activity. These results are in close proximity with Prashanth and Patil (2013). Non-significant differences for grain and stover yields of maize, uptake of nutrients, organic carbon, available NPK and soil microbial activity were noticed due to interaction of tillage and nutrient management through target yield approaches.
Effect of crop residue, tillage practices and target yield approach on succeeding wheat

The differences in yield contributing attributes of wheat due to target yield approach followed for maize did not differ due to target yield approaches. However, higher values of these yield parameters were registered in the plot which received nutrients for target yield of $10 \mathrm{t} \mathrm{ha}^{-1}$ compared to other treatments. The increase in these yield parameters might be attributed to residual effect of nutrients applied through target yield in preceding maize. Zero tillage with mulch @ $5 \mathrm{t} \mathrm{ha}^{-1}$ was found to increase the grain yield of wheat by 6.95 and 3.83 per cent over conventional tillage. Thus, the same treatment produced relatively higher straw yield and harvest index. The findings of and Gangawar et al., (2004) also fell in line with the findings of Jat et al., (2010). They observed that the residual effect of Sesbania green manuring + wheat straw and Sesbania green manuring alone used in preceding maize affected significantly the yield of succeeding wheat. Interaction effect due to tillage and target yield approach did not influence succeeding wheat crop.

\section{Economics of tillage and nutrient management practices in maize - wheat cropping system}

Maize equivalent yield of wheat was not influenced due to different tillage practices. However, higher maize equivalent yield was obtained in zero tillage with mulch@ $5 \mathrm{t} \mathrm{ha}^{-1}$. The lower maize equivalent yield was recorded with conventional tillage. The different target yield approaches differed significantly. Significantly higher maize equivalent yield was recorded in target yield of $10 \mathrm{t} \mathrm{ha}^{-1}$. The lowest maize equivalent yield was obtained in conventional tillage followed by RDF. 
Table.1 Organic carbon and available N. P and K of soil and Soil micro flora as influenced by different tillage and target yield approaches in maize - wheat cropping system (Mean of two years)

\begin{tabular}{|c|c|c|c|c|c|c|c|}
\hline \multirow[t]{2}{*}{ Treatment } & \multirow{2}{*}{$\begin{array}{c}\text { Organic } \\
\text { carbon } \\
(\%)\end{array}$} & \multirow{2}{*}{$\begin{array}{c}\text { Available } \\
\text { N } \\
\left(\mathrm{kg} \mathrm{ha}^{-1}\right)\end{array}$} & \multirow{2}{*}{$\begin{array}{c}\text { Available P } \\
\left(\mathrm{kg} \mathrm{ha}^{-1}\right)\end{array}$} & \multirow{2}{*}{$\begin{array}{l}\text { Available K } \\
\left(\mathrm{kg} \mathrm{ha}^{-1}\right)\end{array}$} & \multicolumn{3}{|c|}{ Soil micro flora (No.x10 ${ }^{6} \mathrm{CFU} \mathrm{g}^{-1}$ ) } \\
\hline & & & & & Initial & Middle & At harvest \\
\hline \multicolumn{8}{|l|}{ Main plots (M) } \\
\hline$M_{1}$ - Conventional tillage & 0.44 & 207.51 & 44.80 & 288.50 & 45.60 & 54.25 & 47.63 \\
\hline $\mathbf{M}_{2}$ - Zero tillage & 0.51 & 238.94 & 50.51 & 332.20 & 52.46 & 61.03 & 53.80 \\
\hline $\begin{array}{l}M_{3} \text { - Zero tillage with mulch } \\
\text { @ } 5 \mathrm{t} / \mathrm{ha}\end{array}$ & 0.54 & 243.91 & 51.88 & 339.10 & 54.60 & 63.22 & 55.72 \\
\hline S. Em \pm & 0.02 & 13.00 & 1.11 & 17.40 & 2.14 & 2.40 & 2.90 \\
\hline C.D. (0.05) & NS & NS & 4.47 & NS & 5.89 & 6.72 & NS \\
\hline \multicolumn{8}{|l|}{ Sub plots $(\mathbf{S})$} \\
\hline$S_{1}$ - Targeted yield (6 t / ha) & 0.50 & 231.30 & 49.18 & 321.57 & 51.21 & 59.72 & 52.10 \\
\hline$S_{2}$ - Targeted yield (8 t / ha) & 0.52 & 243.16 & 52.25 & 339.81 & 54.19 & 62.84 & 55.37 \\
\hline $\mathrm{S}_{3}$ - Targeted yield (10 t / ha) & 0.56 & 259.53 & 55.48 & 360.83 & 58.06 & 66.71 & 58.11 \\
\hline $\mathbf{S}_{4}-\mathbf{R D F}$ & 0.44 & 208.62 & 44.18 & 290.05 & 45.17 & 53.89 & 48.30 \\
\hline $\mathrm{S}_{5}-150 \% \mathrm{RDF}$ & 0.51 & 238.85 & 50.67 & 330.32 & 52.54 & 61.19 & 53.50 \\
\hline$S_{6}$ - Farmer's practice & 0.43 & 199.26 & 42.64 & 277.02 & 44.13 & 52.66 & 46.91 \\
\hline S. Em \pm & 0.04 & 21.50 & 2.10 & 16.10 & 2.81 & 2.81 & 4.00 \\
\hline C.D. (0.05) & NS & NS & 6.10 & 46.60 & 8.14 & 8.16 & NS \\
\hline \multicolumn{8}{|l|}{ Interaction (M x S) } \\
\hline S. Em \pm & 0.05 & 20.82 & 2.71 & 28.94 & 4.93 & 4.94 & 4.24 \\
\hline C.D. (0.05) & NS & NS & NS & NS & NS & NS & NS \\
\hline
\end{tabular}

NS - Non significant 
Table.2 NPK uptake of maize as influenced by different tillage and target yield approaches in maize - wheat cropping system (Mean of two years)

\begin{tabular}{|c|c|c|c|}
\hline Treatment & $\mathrm{N}$ uptake $\left(\mathrm{kg} \mathrm{ha}^{-1}\right)$ & P uptake (kg ha $\left.{ }^{-1}\right)$ & K uptake (kg ha $\left.{ }^{-1}\right)$ \\
\hline \multicolumn{4}{|l|}{ Main plots (M) } \\
\hline$M_{1}$ - Conventional tillage & 138.41 & 27.64 & 98.49 \\
\hline $\mathbf{M}_{2}$ - Zero tillage & 159.36 & 31.90 & 113.54 \\
\hline$M_{3}$ - Zero tillage with mulch @ $5 \mathrm{t} / \mathrm{ha}$ & 162.68 & 32.45 & 115.62 \\
\hline S. Em \pm & 8.66 & 1.72 & 6.12 \\
\hline C.D. (0.05) & NS & NS & NS \\
\hline \multicolumn{4}{|l|}{ Sub plots (S) } \\
\hline$S_{1}$ - Targeted yield (6 t / ha) & 154.28 & 30.99 & 109.78 \\
\hline$S_{2}$ - Targeted yield (8 t / ha) & 163.03 & 32.57 & 116.00 \\
\hline $\mathrm{S}_{3}$ - Targeted yield (10 t / ha) & 173.08 & 34.59 & 123.17 \\
\hline $\mathrm{S}_{4}-\mathbf{R D F}$ & 139.15 & 27.80 & 99.01 \\
\hline $\mathrm{S}_{5}-150 \% \mathrm{RDF}$ & 158.48 & 31.50 & 112.76 \\
\hline$S_{6}$ - Farmer's practice & 132.90 & 26.56 & 94.57 \\
\hline S. Em \pm & 7.71 & 1.54 & 5.48 \\
\hline C.D. (0.05) & 22.40 & 4.48 & 15.91 \\
\hline \multicolumn{4}{|l|}{ Interaction (M x S) } \\
\hline S. Em \pm & 13.88 & 2.78 & 9.87 \\
\hline C.D. (0.05) & NS & NS & NS \\
\hline
\end{tabular}

NS - Non significant 
Table.3 Yield parameters of maize and wheat at harvest as influenced by different tillage practices and target yield approaches in maize - wheat cropping system (Mean of two years)

\begin{tabular}{|c|c|c|c|c|c|c|c|c|c|}
\hline \multirow[t]{2}{*}{ Treatment } & \multicolumn{5}{|c|}{ Maize } & \multicolumn{4}{|c|}{ Wheat } \\
\hline & $\begin{array}{l}\text { Cob length } \\
\quad(\mathrm{cm})\end{array}$ & $\begin{array}{c}\text { Cob } \\
\text { girth } \\
(\mathrm{cm})\end{array}$ & $\begin{array}{c}\text { Number } \\
\text { of grains } \\
\text { per cob }\end{array}$ & $\begin{array}{c}\text { Grain } \\
\text { weight } \\
\left(\text { g plant }^{-1}\right)\end{array}$ & $\begin{array}{c}\text { Test } \\
\text { weight } \\
\text { (g) }\end{array}$ & $\begin{array}{c}\text { Number } \\
\text { of } \\
\text { effective } \\
\text { tillers }\end{array}$ & $\begin{array}{l}\text { Number } \\
\text { of grains } \\
\text { per spike }\end{array}$ & $\begin{array}{c}\text { Grain } \\
\text { weight } \\
\text { per spike } \\
\text { (g) }\end{array}$ & $\begin{array}{c}\text { Test } \\
\text { weight } \\
\text { (g) }\end{array}$ \\
\hline \multicolumn{10}{|l|}{ Main plots (M) } \\
\hline$M_{1}$ - Conventional tillage & 12.71 & 10.99 & 348.44 & 169.88 & 22.70 & 193.61 & 27.22 & 1.50 & 34.70 \\
\hline $\mathbf{M}_{2}$ - Zero tillage & 14.32 & 12.51 & 406.15 & 179.70 & 23.89 & 196.59 & 28.20 & 1.57 & 35.76 \\
\hline $\begin{array}{l}\text { M3-Zero tillage with mulch@5 t / } \\
\text { ha }\end{array}$ & 14.92 & 12.87 & 426.71 & 184.91 & 24.58 & 198.88 & 30.39 & 1.66 & 37.53 \\
\hline S. Em \pm & 0.76 & 0.67 & 27.90 & 5.30 & 0.67 & 8.27 & 1.13 & 0.05 & 1.02 \\
\hline C.D. (0.05) & NS & NS & NS & NS & NS & NS & NS & NS & NS \\
\hline \multicolumn{10}{|l|}{ Sub plots $(\mathbf{S})$} \\
\hline $\mathrm{S}_{1}$ - Targeted yield (6 t / ha) & 14.09 & 12.08 & 402.19 & 178.49 & 23.75 & 193.77 & 28.00 & 1.53 & 35.62 \\
\hline $\mathrm{S}_{2}$ - Targeted yield (8 t / ha) & 15.04 & 13.22 & 431.80 & 186.20 & 24.83 & 199.26 & 29.70 & 1.75 & 38.94 \\
\hline $\mathrm{S}_{3}$ - Targeted yield (10 t / ha) & 15.65 & 13.91 & 462.30 & 188.77 & 25.14 & 205.68 & 32.27 & 1.91 & 39.27 \\
\hline $\mathbf{S}_{4}-\mathbf{R D F}$ & 12.57 & 10.60 & 333.73 & 169.82 & 22.58 & 193.22 & 27.16 & 1.42 & 33.16 \\
\hline $\mathrm{S}_{5}-150 \% \mathrm{RDF}$ & 14.47 & 12.79 & 419.33 & 181.87 & 24.29 & 196.06 & 28.45 & 1.60 & 37.48 \\
\hline$S_{6}$ - Farmer's practice & 12.07 & 10.15 & 313.26 & 163.80 & 21.76 & 190.17 & 25.84 & 1.25 & 31.52 \\
\hline S. Em \pm & 0.70 & 0.70 & 29.19 & 5.44 & 0.72 & 6.09 & 1.52 & 0.18 & 2.22 \\
\hline C.D. (0.05) & 2.06 & 2.03 & 84.71 & 15.78 & 2.08 & NS & NS & NS & NS \\
\hline \multicolumn{10}{|l|}{ Interaction (M x S) } \\
\hline S. Em \pm & 1.23 & 1.23 & 51.55 & 9.52 & 1.26 & 12.69 & 1.35 & 0.12 & 2.49 \\
\hline C.D. (0.05) & NS & NS & NS & NS & NS & NS & NS & NS & NS \\
\hline
\end{tabular}

NS - Non significant 
Table.4 Grain yield, stover yield and harvest index of maize and grain yield, straw yield and harvest index of wheat as influenced by different tillage practices and target yield approaches in maize - wheat cropping system (Mean of two years)

\begin{tabular}{|c|c|c|c|c|c|c|c|c|}
\hline \multirow[t]{2}{*}{ Treatment } & \multicolumn{2}{|c|}{ Maize } & \multicolumn{2}{|c|}{ Wheat } & \multirow{2}{*}{$\begin{array}{c}\text { Maize } \\
\text { equivalent } \\
\text { yield of } \\
\text { wheat } \\
\left(\mathbf{q} \mathbf{h a}^{-1}\right)\end{array}$} & \multirow{2}{*}{$\begin{array}{l}\text { System } \\
\text { productivity } \\
\left(\mathbf{q ~ h a} \mathbf{a}^{-1}\right)\end{array}$} & \multirow{2}{*}{$\begin{array}{c}\text { Net } \\
\text { returns } \\
\left(\mathrm{Rs} \mathrm{ha}^{-1}\right)\end{array}$} & \multirow[t]{2}{*}{ B C ratio } \\
\hline & $\begin{array}{c}\text { Grain } \\
\text { yield of } \\
\text { maize } \\
\left(\mathbf{q} \text { ha }^{-1}\right)\end{array}$ & $\begin{array}{c}\text { Straw } \\
\text { yield } \\
\left(\mathbf{q} \text { ha }^{-1}\right)\end{array}$ & $\begin{array}{l}\text { Grain yield } \\
\quad\left(\mathrm{q} \mathrm{ha} \mathbf{~ h}^{-1}\right)\end{array}$ & $\begin{array}{c}\text { Straw yield } \\
\qquad\left(\mathbf{q} \mathbf{h a}^{-1}\right)\end{array}$ & & & & \\
\hline \multicolumn{9}{|l|}{ Main plots (M) } \\
\hline$M_{1}$ - Conventional tillage & 55.8 & 76.5 & 18.99 & 25.20 & 21.5 & 77.3 & 62112 & 1.55 \\
\hline $\mathbf{M}_{2}$ - Zero tillage & 64.3 & 84.2 & 19.56 & 25.94 & 22.1 & 86.5 & 78181 & 2.19 \\
\hline $\begin{array}{l}\text { M3-Zero tillage with mulch@ } 5 \text { t / } \\
\text { ha }\end{array}$ & 65.9 & 88.3 & 20.32 & 26.85 & 23.0 & 88.9 & 80272 & 2.18 \\
\hline S. Em \pm & 3.60 & 4.21 & 0.57 & 0.89 & 1.19 & 1.46 & 1920 & 0.06 \\
\hline C.D. (0.05) & NS & NS & NS & NS & NS & 5.99 & 7745 & 0.24 \\
\hline \multicolumn{9}{|l|}{ Sub plots $(\mathbf{S})$} \\
\hline $\mathrm{S}_{1}$ - Targeted yield (6 t / ha) & 62.7 & 83.5 & 20.20 & 26.47 & 22.9 & 85.5 & 76472 & 2.13 \\
\hline $\mathbf{S}_{2}$ - Targeted yield (8 t / ha) & 65.8 & 86.7 & 20.91 & 27.84 & 23.7 & 89.5 & 80565 & 2.17 \\
\hline $\mathrm{S}_{3}$ - Targeted yield (10 t / ha) & 69.9 & 89.5 & 21.72 & 29.47 & 24.6 & 94.5 & 85105 & 2.18 \\
\hline $\mathbf{S}_{4}-\mathbf{R D F}$ & 56.2 & 78.3 & 18.23 & 24.63 & 20.6 & 76.8 & 63672 & 1.72 \\
\hline $\mathrm{S}_{5}-150 \% \mathrm{RDF}$ & 64.0 & 85.7 & 20.49 & 26.70 & 23.2 & 87.2 & 74198 & 1.84 \\
\hline $\mathbf{S}_{6}$ - Farmer's practice & 53.6 & 74.3 & 16.17 & 20.86 & 18.3 & 71.9 & 61119 & 1.85 \\
\hline S. Em \pm & 3.1 & 2.9 & 0.95 & 1.19 & 0.97 & 3.04 & 4006 & 0.11 \\
\hline C.D. (0.05) & 9.1 & 9.0 & NS & NS & 2.80 & 8.82 & 11626 & 0.32 \\
\hline \multicolumn{9}{|l|}{ Interaction (M x S) } \\
\hline S. Em \pm & 5.6 & 5.5 & 1.39 & 2.08 & 1.94 & 3.58 & 4705 & 0.14 \\
\hline C.D. (0.05) & NS & NS & NS & NS & NS & NS & NS & NS \\
\hline
\end{tabular}

NS - Non significant 
The interaction effect due to tillage practices as well as target yield approaches did not differ. System productivity of maize - wheat cropping system differed significantly due to different tillage practices. Zero tillage with mulch@ $5 \mathrm{t} \mathrm{ha}^{-1}$ recorded significantly higher system productivity. The lowest system productivity was registered with conventional tillage. The different target yield approaches differed significantly for system productivity. Target yield of $10 \mathrm{t} \mathrm{ha}^{-1}$ was significantly higher for system productivity. Significantly the lowest system productivity was recorded in conventional tillage. The interaction effect due to tillage practices as well as target yield approaches did not differ.

Net returns and B:C affected due to tillage practices. Significantly higher net returns (Rs.80,272 $\mathrm{ha}^{-1}$ ) were recorded with zero tillage with mulch @ $5 \mathrm{t} \mathrm{ha}^{-1}$ followed by zero tillage (Rs.78,181 $\mathrm{ha}^{-1}$ ) compared to conventional tillage (Rs. 62,112 ha ${ }^{-1}$ ). The net returns and $\mathrm{B}: \mathrm{C}$ ratio differed significantly due to target yield approach. Significantly higher net returns (Rs.85,105 ha ${ }^{-1}$ ) was recorded in target yield of $10 \mathrm{t} \mathrm{ha}^{-1}$ followed by target yield of $8 \mathrm{t} \mathrm{ha}^{-1}$ (Rs. 80,565 ha-1). The lowest net returns (Rs.61,119 ha-1) was obtained with farmers practice followed by RDF (Rs.63,672 $\mathrm{ha}^{-1}$ ). The interaction effect due to tillage practices as well as target yield approaches did not differ.

In conclusion, zero tillage with mulch@5 t $\mathrm{ha}^{-1}$ followed by zero tillage alone produced relatively higher yields compare to conventional tillage and it was found to be better for improving the soil organic carbon, soil microflora, available NPK and uptake of crop. Further, target yield of $10 \mathrm{t} \mathrm{ha}^{-1}$ followed by target yield of $8 \mathrm{t} \mathrm{ha}^{-1}$ exhibited significantly higher yield and improving the soil organic matter, soil microflora, available NPK and nutrient uptake of crop. Thus, application of nutrients through targeted yield approach is more useful and profitable since benefit cost ratio is higher compared to application of farmers practice and 100 per cent RDF + FYM @ $10 \mathrm{tha}^{-1}$. Application of nutrients through targeted yield approach in combination with organic source is more useful in maintenance of soil organic carbon, available NPK and microbial load and sustainability.

\section{Acknowledgement}

The senior author is thankful to University of Agricultural Sciences, Raichur for providing an opportunity to study the higher education on deputation.

\section{References}

Alvear, M., Rosas, A., Rouanet, J. L. and Borie, F., 2005, Effect of three soil tillage systems on some biological activities in an Ultisol from Southern Chile. Soil Tillage Res., 82: 195-202.

Ashok Biradar and Jayadeva, H. M., 2013, Influence of target yield approach on yield, yield attributes, nutrient uptake and economics of maize. Madras Agric. J., 100(1-2): 146-149.

Bahar, F. A., 2013, Relative performance of resource conservation technologies in maize based cropping system under temperate Kashmir. Trends Biosci., 6(1): 43-45.

Dhillon, N. S., Brar, B. S., Benipal, D. S. and Mavi, M. S., 2006, Economics of various soil test based fertilization approaches for different crops. Crop Res., 32(3): 377-381.

Gangawar, K. S., Sharma, S. K. and Tomar, O. K., 2004, Alley cropping of subabul (Leucaena leucocephala L.) for sustaining higher crop productivity and soil fertility of rice (Oryza sativa L.) wheat (Triticum aestivum L.) system in semi arid conditions. Indian J. Agron., 
49 (2): 84-88.

Govaerts, B., Mezzalama, M., Sayre, K. D., Crossa Lichter, K., Troch, V., Vanherck, K., De Corte, P. and Deckers, J., 2008, Long term consequences of tillage, residue management and crop rotation on selected soil micro flora groups in the sub tropical highlands. Appl. Soil Ecol., 38: 197-210.

Jat, N. K., Ashok kumar, and Shivadhar., 2010. Influence of Sesbania green manure with or without wheat residues and $\mathrm{N}$ fertilization on maize (Zea mays L.) - wheat (Triticum aestivum L.) cropping system. Indian Journal of Agronomy. 55(4): 253-258.

Mann, R. A., Ramzan, M. and Munir, A., 2008, Improving the sustainability of wheat production in irrigated areas of Punjab, Pakistan through conservation technology. Int. J. Agric. Biol., 10: 249254.

Prashanth and Patil, 2013, Nutrient management as influenced by tillage and crop residue management in maize (Zea mays L.). M.Sc (Agri.) Thesis, University of Agricultural Sciences, Raichur.

Paramasivan, M., Malarvizhi, P. and Thiyageswari, 2012, Balanced use of inorganic fertilizer on? 55r4tr3maize (Zea mays L.) yield, nutrient uptake and soil fertility in Alfisols. Karnataka $J$. Agric. Sci., 25 (4): 423-426.

Pooniya, V., Jat, S. L., Choudhary, A. K., Singh, A. K., Parihar, C. M., Bana, R. S., Swarnlakshmi, K. and Rana, K. S.,
2015, Nutrient expert assisted sitespecific-nutrient-management: An alternative precision fertilization technology for maize-wheat cropping system in South Asian Indo-Gangetic Plains. Indian J. Agric. Sci., 85(8): 9961002.

Ramachandrappa, B. K., Sathish, A., Dhanapal, G. N., Shankar, M. A. and Srikanthbabu, P. N., 2015, Moisture conservation and site specific nutrient management for enhancing productivity in rainfed finger millet + pigeonpea intercropping system in Alfisols of South India. Indian J. Soil. Conservation, 43(1): 72-78.

Sharma, S. K. and Jain, N. K., 2014, Nutrient management in wheat (Triticum aestivum L.)-based cropping systems in sub-humid southern zone of Rajasthan. Indian J. Agron., 59(1): 26-33.

Shreeharshakumar, S.S. and Gaddanakeri, S.A., 2015, Site specific nutrient management for target yield and recovery in sugarcane. Karnataka $J$. Agric. Sci., 28(1): 16-19.

Singh, Y. P., Singh, D., Tomar, S. S. and Gupta, R. K., 2013, Effect of time of pre-irrigation and tillage practices on wheat under pigeonpea-wheat cropping sequence. Indian J. Agric. Sci., 83(12): 1317-1321.

Yaseen, R., Shafi, J., Ahmad, W., Rana, M. S., Salim, M. and Quisrani, A., 2014, Effect of deficit irrigation and mulch on soil physical properties, growth and yield of maize. Environment Ecol. Res., 2(3):122-137.

\section{How to cite this article:}

Hiremath, K. A., A. S. Halepyati, B. M. Dodamani, M. A. Bellakki, B. M. Chittapur, P. H. Kuchanur and Ameregouda. 2020. Enhancing Soil Health and Productivity of Maize - Wheat Cropping System with Balanced Nutrients Application through Target Yield Approach under Different Tillage Practices. Int.J.Curr.Microbiol.App.Sci. 9(02): 1249-1259. doi: https://doi.org/10.20546/ijcmas.2020.902.148 